\title{
Call for Nomination Book Reviews Editor
}

Invitation for Nominations and Requirements for the Editorial Position of Book Reviews Editor of Religion \& Theology.

Book reviews and review articles are an important part of scholarly discourse. Being the occasion for authoritative comment on current scholarly discourses, it should be given much greater attention and prominence in the journal. In order to build out this aspect of our publication, as well as to fill the current vacant position of book reviews editor, this call for nominations is made public.

Nominations are invited for the position of book reviews editor of Religion \& Theology. A Journal of Contemporary Religious Discourse. Nominations will be accepted until 31 January 2020 after which date the editorial committee will evaluate nominations and make the appointment. The appointee will receive instruction in the managing of reviews submissions via the submissions portal, Editorial Manager.

Nominations should include a CV, as well as a statement as to how the nominee fills the requirements of the position, and if available, some examples of book reviews or articles written by the nominee.

- The position of book reviews editor is open to any qualified academic in the broad field of the study of religion and theology, who may be a senior scholar or an early career academic. However, Religion \& Theology invites nominations for the position of book reviews editor particularly from early career academics.

- It is expected that the successful appointee will have a $\mathrm{PhD}$ in one of the disciplines within the broader fields of the study of religion and theology, and preferably not be a newly qualified candidate but will have had some experience of presenting at conferences and networking.

- While it is not required that the appointee will already have published a substantial number of peer-reviewed articles or a monograph, these will be recommendations. It is expected that the appointee will have experience of writing book reviews and/or review articles.

- The book reviews editor will, ideally, either have a current appointment at an institution of higher learning, or an affiliation with such an institution.

- The book reviews editor will be fluent in English and be able to take responsibility for copy editing submitted reviews or review articles. 
- Since Religion \& Theology promotes the transdisciplinary metareflection on the discourses of the study of religion and the study of theology, and in their interrelatedness, the book reviews editor will be a scholar who has a broad overview of current discourses in these fields as well as broad knowledge of publishers in these fields. In general, the book reviews editor should identify him/herself with the Scope and Aims of the journal as spelt out on the website, as well as in the programmatic statements in Gerhard van den Heever, "Introduction. Reflections on the Ampersand: A Manifesto of Sorts, Etc. Etc.," Religion \& Theology 26/1\&2 (2019): 1-39; Gerhard van den Heever, "Editor's Preface," Religion \& Theology 25/3\&4 (2018): 153-154, and Russell T. McCutcheon, "Introduction. An Experiment in Redescription," Religion \& Theology 25/3\&4 (2018): 155-160.

Tasks the book reviews editor should fulfil:

1. The book reviews editor is responsible for arranging a substantial amount of reviews of books that are of interest to the readers of Religion \& Theology.

2. Accept and edit/copy-edit the reviews after having been submitted. Manage the process of steering book reviews and review articles, from submission to transmission to production, on the Editorial Manager platform. This requires intimate working knowledge of the Editorial Manager platform and the book reviews editor should take all steps required to remain proficient in working on this platform.

3. After publication of book reviews, send e-copies of these to the relevant publishers.

4. Identify and solicit books for review from publishers in accordance with the Scope and Aim of Religion \& Theology, and with a view to the intended readership of the journal. This implies as well a search for book reviewers with the necessary expertise to review these books and asking them to write a review.

5. Invite book reviewers to write and submit book reviews to the journal.

6. Plan review articles in consultation with the editor and execute the organisation of these.

7. Consult regularly with the editor and the editorial committee of Religion \& Theology.

Inquiries can be made to the Executive Editor: Religion \& Theology, Prof. Gerhard van den Heever, vdheega@unisa.ac.za. 